\title{
ADDENDA TO THE KNOWN FLORA OF THE BESNARD LAKE AREA, NORTH-CENTRAL SASKATCHEWAN
}

MIRANDA M. HART, 316 Arthur Ave., Saskatoon, SK. S7N 1J3 and VERNON L. HARMS, Fraser Herbarium, University of Saskatchewan, Agriculture Bldg., 51 Campus Drive, Saskatoon, SK. S7N 5A8.

A recent article by V.L. Harms and Anna Leighton, published in the December 1994 issue of this journal, recorded a known flora of 210 species of vascular plants in the general Besnard Lake area in north-central Saskatchewan. ${ }^{1}$ That inventory list was not considered complete but rather a starting point for finding additional records from the area. Subsequently, during the 1995 summer, Miranda Hart made a collection of about 70 plant species from the Besnard Lake area, including 20 species that were in addition to those of the 1994 Harms/Leighton list. These we consider worth reporting, as the brief list below, to add them to the overall list for the area.

The revised summary of plants now recorded for the general Besnard Lake area totals 230 species, of 143 genera, in 60 families of vascular plants, including 15 species of pteridophytes (= ferns and fern- allies), 6 species of coniferous gymnosperms, and 209 species of angiosperms (= flowering plants). Less than $5 \%$ (10 of 230 ) represent introduced species (i.e. either invasive weeds or escaped cultigens; these are indicated by asterisks below).

Among the new additions, the Small White Water-lily (Nymphaea tetragona var. leibergii) is a provincially rare species. The present record helps to better bridge the previously apparent gap between more southern and more northern records in boreal Saskatchewan. Three of the new additions represent significant northward extensions of the known species ranges in the province. These are Pink-flowered Onion (Allium stellatum), Low Pussytoes (Antennaria aprica), and Western Pygmy-flower (Androsace occidentalis).

All collection numbers (prefixed with "MH") on the list below are those of Miranda Hart. Verified voucher specimens documenting the below-listed as well as the other Besnard Lake plants are filed in The W.P. Fraser Herbarium (SASK), University of Saskatchewan, Saskatoon, SK.

ASTERACEAE (Aster or Composite Family):

Antennaria aprica Greene - Low Pussytoes. MH-7.

Artemisia campestris L. - Plains or Tall Wormwood. MH-8.

Erigeron glabellus Nutt. - Smooth Fleabane. $\mathrm{MH}-10$.

Taraxacum laevigatum (Willd.) DC. Red-seeded Dandelion. $\mathrm{MH}-15$ 
FABACEAE (Legume or Pea Family): Astragalus agrestis Dougl. (A. hypoglottis; $A$. danicus) - Purple Milkvetch. $\mathrm{MH}-30$.

Trifolium pratense L. - Red Clover. $\mathrm{MH}-34$.

LAMIACEAE (Mint Family):

Scutellaria galericulata L. (S. epifoliifolia) - Marsh Skullcap. MH-37.

LENTIBULARIACEAE (Bladderwort Family):

Utricularia vulgaris L. - Common or Greater Bladderwort. MH39.

LILIACEAE (Lily Family):

Allium stellatum Fraser - Pinkflowered or Prairie Onion. MH-40.

NYMPHAEACEAE (Water-lily Family): Nymphaea tetragona Georgi spp. leibergii (Morong) Porsild

- Small White Water-lily. MH-50. (R).

POLEMONIACEAE (Phlox Family):

Collomia linearis Nutt. - Narrowleaved Collomia. MH-60.

PRIMULACEAE (Primrose Family): Androsace occidentalis Pursh Western Pygmy-flower; Fairy Candelabra. MH-64.

\section{RANUNCULACEAE}

Family):

Anemone patens L. (Pulsatilla Iudoviciana) - Prairie Crocus; Crocus
Anemone; Pasque-flower. MH-74.

Thalictrum venulosum Trel. - Veiny Meadow-rue. MH-79.

ROSACEAE (Rose Family):

Fragaria vesca $\mathrm{L}$. var. americana Porter - American Wood Strawberry. $\mathrm{MH}-75$.

Potentilla fruticosa L. - Shrubby Cinquefoil. MH-76.

Prunus virginiana L. - Choke Cherry. $\mathrm{MH}-80$.

Rubus acaulis Michx. - Dwarf or Stemless Raspberry; Arctic Dewberry; Dwarf Nagoonberry. MH-83.

SARRACENIACEAE (Pitcher-plant Family):

Sarracenia purpurea L. - Pitcherplant. MH-87.

SPARGANIACEAE (Bur-reed Family): Sparganium minimum Fries - Small Bur-reed. MH-90.

Acknowledgements Thanks are extended to Dr. Gary R. Bortolotti, Biology Department, University of Saskatchewan, for employing the senior author during the 1995 summer at the University's Besnard Lake Field Station.

1. HARMS, Vernon L. and Anna LEIGHTON. 1994. Flora of the Besnard Lake area, north-central Saskatchewan. Blue Jay 52:190-199. 